\title{
PERAN GURU DALAM PEMBELAJARAN PADA SISWA SEKOLAH DASAR
}

\author{
Dea Kiki Yestiani \& Nabila Zahwa \\ Universitas Muhammadiyah Tangerang \\ deakiki1@gmail.com
}

\begin{abstract}
Lack of understanding of children's learning can be caused by several factors. One of them is the lack of teacher's role in the learning process at school can cause children's understanding to decrease, especially in elementary school children. The role of teachers in primary schools is still very much needed because elementary school children still lack the comprehension of what they see and hear. With this phenomenon, research is conducted to find out how the role of teachers in learning in schools among elementary school students.
\end{abstract}

Keywords: Teacher Role, Learning

\begin{abstract}
Abstrak: Kurangnya pemahaman pada pembelajaran anak dapat disebabkan oleh beberapa faktor. Salah satunya yaitu kurangnya peran guru dalam proses pembelajaran di sekolah dapat menyebabkan pemahaman anak berkurang khususnya pada anak sekolah dasar. Peran guru di sekolah dasar masih sangat diperlukan karena anak sekolah dasar masih kurangnya daya tangkap merreka terhadap sesuatu yang mereka lihat dan mereka dengar. Dengan adanya fenomena tersebut maka dilakukan penelitian yang bertujuan untuk mengetahui bagaimana peran guru dalam pembelajaran di sekolah pada siswa sekolah dasar.
\end{abstract}

Kata Kunci: Peran Guru, Pembelajaran

\section{PENDAHULUAN}

Menurut Kamus Besar Bahasa Indonesia (2008:509) Guru adalah orang yang pekerjaannya mengajar. Menurut Thoifuri (2007:1) Kata guru dalam bahasa arab disebut mu'allim dan dalam bahasa inggris dikenal dengan teacher yang dalam pengertian yang sederhana merupakan seseorang yang pekerjaannya mengajar orang lain. Menurut Annisa Anita Dewi $(2017 ; 10)$ guru merupakan seorang pendidik yang digugu dan ditiru, dalam hal ini guru menjadi teladan bagi anak didiknya.

Pembelajaran adalah proses interaksi peserta didik dengan pendidik dan sumber belajar pada suatu lingkungan belajar. Pembelajaran merupakan bantuan yang diberikan pendidik agar dapat terjadi proses perolehan ilmu dan pengetahuan, penguasaan kemahiran dan tabiat, serta pembentukan sikap dan kepercayaan pada

Fondatia : Jurnal Pendidikan Dasar

Volume 4, Nomor 1, Maret 2020; 41-47

https://ejournal.stitpn.ac.id/index.php/fondatia 
setiap peserta didik. Dengan kata lain, pembelajaran adalah proses untuk membantu peserta didik agar dapat belajar dengan baik. Proses pembelajaran dialami sepanjang hayat seseorang manusia serta dapat berlaku di manapun dan kapanpun. (Menurut Moh.Suardi,2018;7)

Dalam kegiatan belajar mengajar, guru memiliki peran yang cukup penting untuk membuat ilmu-ilmu yang diajarkan dapat diterima oleh siswa-siswa yang ada. Tak hanya berperan untuk mengajarkan ilmu-ilmu saja, banyak sekali peran guru dalam proses pembelajaran. Nah kali ini akan dibahas lebih lanjut mengenai peran guru di dalam proses kegaiatan belajar mengajar.

1. Guru Sebagai Pendidik

Guru merupakan pendidik, tokoh, panutan serta identifikasi bagi para murid yang di didiknya serta lingkungannya. Oleh sebab itu, tentunya menjadi seorang guru harus memiliki standar serta kualitas tertentu yang harus dipenuhi. Sebagai seorang guru, wajib untuk memiliki rasa tanggung jawab, mandiri, wibawa, serta kedisiplinan yang dapat dijadikan contoh bagi peserta didik.

\section{Guru Sebagai Pengajar}

Kegiatan belajar mengajar akan dipengaruhi oleh beragam faktor di dalamnya, mulai dari kematangan, motivasi, hubungan antara murid dan guru, tingkat kebebasan, kemampuan verbal, ketrampilan guru di dalam berkomunikasi, serta rasa aman. Jika faktor faktor tersebut dapat terpenuhi, maka kegiatan belajar mengajar dapat berlangsung dengan baik. Guru harus dapat membuat sesuatu hal menjadi jelas bagi murid, bahkan terampil untuk memecahkan beragam masalah.

3. Guru Sebagai Sumber Belajar

Peran guru sebagai sebuah sumber belajar akan sangat berkaitan dengan kemampuan guru untuk menguasai materi pelajaran yang ada. Sehingga saat siswa bertanya sesuatu hal, guru dapat dengan sigap dan tanggap menjawab pertanyaan murid dengan menggunakan bahasa yang lebih mudah dimengerti. 


\section{Guru Sebagai Fasilitator}

Peran seorang guru sebagai fasilitator adalah dalam memberikan pelayanan agar murid dapat dengan mudah menerima dan memahami materi-materi pelajaran. Sehingga nantinya proses pembelajaran akan menjadi lebih efektif dan efisien.

5. Guru Sebagai Pembimbing

Guru dapat dikatakan sebagai pembimbing perjalanan, yang mana berdasar pengetahuan serta pengalamannya dan memiliki rasa tanggung jawab dalam kelancaran perjalanan tersebut. Perjalanan ini tidak hanya sola fisik namun juga perjalanan mental, kreatifitas, moral, emosional dan spritual yang lebih kompleks dan dalam.

\section{Guru Sebagai Demonstrator}

Guru memiliki peran sebagai demonstator adalah memiliki peran yang mana dapat menunjukkan sikap-sikap yang bisa menginspirasi murid untuk melakukan hal-hal yang sama bahkan dapat lebih baik.

7. Guru Sebagai Pengelola

Dalam proses kegiatan belajar mengajar, guru memiliki peran dalam memegang kendali atas iklim yang ada di dalam suasana proses pembelajaran. Dapat diibaratkan jika guru menjadi nahkoda yang memegang kemudi dan membawa kapal dalam perjalanan yang nyaman dan aman. Seorang guru haruslah dapat menciptakan suasana kelas menjadi kondusif dan nyaman.

8. Guru Sebagai Penasehat

Guru berperan menjadi penasehat bagi murid-muridnya juga bagi para orang tua, meskipun guru tidak memiliki pelatihan khusus untuk menjadi penasehat. Murid-murid akan senantiasa akan berhadapan dengan kebutuhan dalam membuat sebuah keputusan dan dalam prosesnya tersebut membutuhkan bantuan guru. Agar guru dapat memahami dengan baik perannya sebagai penasehat serta orang kepercayaan yang lebih dalam maka sudah seharunya guru mendalami mengenai psikologi kepribadian.

9. Guru Sebagai Inovator

Guru menerjemahkan pengalaman yang didapatkannya di masa lalu ke dalam kehidupan yang lebih bermakna untuk murid-murid didikannya. Karena usia 
guru dan murid yang mungkin terlampau jauh, maka tentu saja guru lebih memiliki banyak pengalaman dibandingkan murid. Tugas guru adalah untuk menerjemahkan pengalaman serta kebijakan yang berharga ke dalam bahasa yang lebih modern yang mana dapat diterima oleh murid-murid.

10. Guru Sebagai Motivator

Proses kegiatan belajar mengajar akan berhasil jika murid-murid di dalam nya memiliki motivasi yang tinggi. Guru memiliki peran yang penting untuk menumbuhkan motivias serta semangat di dalam diri siswa dalam belajar.

11. Guru Sebagai Pelatih

Proses pendidikan serta pembelajaran tentunya membutuhkan latihan ketrampilan, entah itu dalam intelektual ataupun motorik. Dalam hal ini guru akan bertindak sebagai pelatih untuk mengembangkan ketrampilan tersebut. Hal ini lebih ditekankan dalam kurikulum 2004 yang mana memiliki basis kompetensi. Tanpa adanya latihan maka tentunya seorang guru tidak akan mampu dalam menunjukkan penguasaan kompetensi dasar serta tidak mahir dalam ketrampilan ketrampilan yang sesuai dengan materi standar.

12. Guru Sebagai Elevator

Setelah proses pembelajaran berlangsung, tentunya seorang guru harus melakukan evaluasi pada hasil yang telah dilakukan selama kegiatan pembelajaran tersebut. Evaluasi ini tidak hanya untuk mengevaluasi keberhasilan siswa untuk mencapai tujuan dalam kegiatan belajar mengajar. Namun juga menjadi evaluasi bagi keberhasilan guru di dalam pelaksanaan kegiatan belajar mengajar. Menurut Khanza Savitra(https://dosenpsikologi.com/peran-guru-dalam-proses-pembelajaran) Adapun tujuan yang dapat terkait mengenai peran guru dalam proses pembelajaran pada siswa sekolah dasar yaitu:

1. Peran guru dalam mengajar di dalam kelas.

2. Peran guru mendidik siswa agar menjadi insan yang bertanggung jawab.

3. Metode pembelajaran yang digunakan dalam mengajar. 


\section{HASIL DAN PEMBAHASAN}

1. Bagaimana cara Ibu memberikan pembelajaran di kelas supaya siswa tidak mudah bosan?

Kalau anak 1 itu kita harus banyak nyanyi,Trus mereka biasa antusias menggunakan alat peraga itu mereka lebih senang misalnya, seperti kerja kelompok atau mereka biasa mengalami langsung. Kalau misalnya mereka sudah bawa alat-alat apa gitu misalkan dari rumah buat kita melakukan pembelajaran di sekolah nah nanti mereka langsung mempraktiknya, biasanya mereka lebih tertarik dibandingkan mereka mendengarkan kita ngomong.

\section{Apa media yang digunakan dalam proses pembelajaran?}

Media yang digunakan macam-macam, seperti kemarin kita finger, mencetak dengan jari, nah itu kan anak-anak harus praktik kalau di kelas satu karena kita masih bersamaan ibaratnya dipakai sama-sama itu biaya untuk alat peraga yang bisa dibeli pakai uang kas kita beli pakai uang kas. Kalau mereka bawa pribadi, kemarin juga Ibu suruh mereka bawa alat-alat kebersihan tubuh tapi kotaknya aja karena kita akan menghitung dan membandingkan banyak benda kebersihan seperti kotak sabun, kotak pepsodent. Mereka satu-satu memperagakan, mereka kasih soal ke temannya, ini misalkan ada kotak sabun 4, disini ada kotak odol misalkan 7 nanti mereka membandingkan kotak sabun lebih banyak atau lebih sedikit dari pada kotak odol. Nah tuh mereka seperti itu, mereka lebih antusias.

\section{Bagaimana cara guru menjelaskan siswa yang tidak paham?}

Biasanya sih dalam satu kelas tidak semuanya paham yah, ada yang mereka enggak fokus, ada yang bercanda dan itu biasanya selalu diingatkan kalau sedang diterangkan atau sedang praktik itu tuh yang serius. Biasany mereka yang memperhatikan dan disitu insyaallah mereka bisa dan yang belum bisa nanti ada pengulangan khusus untuk siswa yang belum bisa itu dari guru. Kalau anak kelas 1 kan karena mereka masih terkendala dengan baca kita ada jam tambahan khusus di luar pembelajaran sih. Itu khusus untuk anak yang belum mengerti, jika yang sudah mengerti dibolehkan pulang. Jadi kita tuh sebagai guru harus membimbing siswa yang belum paham tersebut. Biasanya 
jika tidak selesai bisa dilanjut dirumah. Kalau untuk pembelajaran hari-hari kan dikasih soal masih dibahas jadi belum ketahuan yang belum paham. Karena kan anak kelas 1 itu masih susah kalau disuruh bertanya. Biasanya nanti ketahuannya saat ulangan harian, anak yang tidak bisa itu nanti kita kasih remedial.

\section{Bagaimana cara Ibu mengajar agar suasana menjadi kondusif, karena} kan anak SD terkadang susah untuk dikasih tahu?

Anak kelas 1 itu paling aktif anaknya dan biasanya memang tidak pernah bosan-bosan sih untuk selalu mengingatkan. Biasanya kita bikin perjanjian sama anak-anak walaupun mereka masih kelas 1 mereka harus sudah tahu caranya disiplin, jadi perjanjian nih misalnya sekarang kalau dikasih tahu kalau kamu mendengarkan dan kamu memperhatikan kamu pasti bisa, kalau kamu tidak mendengarkan dan tidak memperhatikan pasti kamu tidak bisa. Lalu mereka suruh milih kamu mau milih bisa atau enggak? Mereka memilih bisa tapi kadang-kadang bercanda lagi, nanti di buat perjanjian lagi siapa yang bercanda nanti akan dibuat tugas. Biasanya kami membuat perjanjian kesepakatan misalnya melanggar tata tertib pada saat belajar mau dikasih

\section{KESIMPULAN}

Peranan guru dalam membina peserta didik menjadi insan yang berkarakter yang baik sangat dibutuhkan. Penggunaan metode yang bervariasi dalam menciptakan suasana belajar agar tidak membosankan untuk menarik minat peserta didik serta menjadi pembina ekstrakulikuler dalam mendekatkan diri kepada peserta didik memudahkan para guru dalam menanamkan nilai-nilai karakter baik. Guru merupakan sosok panutan atau contoh bagi peserta didik. Keberhasilan pendidikan karakter sangat tergantung dari peran seorang guru dalam proses pembelajaran. Jadi sosok seorang guru dapat menjadi cerminan peserta didik yang sangat menentukan karakternya.

Penciptaan suasana kondusif dalam proses belajar mengajar sangat membantu dalam menanamkan karakter anti kekerasan. Penerapan sikap disiplin yang diterapkan guru dalam peraturan kelas berperngaruh dalam keberhasilan proses pembelajaran 
demi menciptakan suasana belajar yang kondusif. Menciptakan suasana kondusif dalam proses belajar mengajar sangat penting. Melalui suasana belajar yang kondusif memudahkan peserta didik untuk memahami materi pelajaran dan dapat membantu pendidik dalam mengajarkan materi yang berhubungan dengan nilai-nilai anti kekerasan.

Guru kelas 1 SD dalam proses pembelajaran kebanyakan setiap guru menggunakan media agar memudahkan anak didiknya untuk dapat memahami apa yang telah dijelaskan serta dalam pembelajaran di kelas 1 guru kebanyakan bernyanyi dan menari agar anak didiknya tidak merasa bosan.

\section{DAFTAR PUSTAKA}

Moh. Suardi. 2018. Belajar \& Pembelajaran. Yogyakarta: Deepublish

Djamarah, Syaiful Bahri. 2010. Guru dan Anak didik dalam Interaksi Edukatif. Jakarta: PT. Rineka cipta

Thoifu. 2007. Menjadi Guru Inisiator. Semarang: Rasail Media Group

Anwar, Muhammad. 2018. Menjadi Guru Profesional. Jakarta: Prenandamedia Group

Tim Penyusun. 2008. Kamus Besar Bahasa Indonesia. Jakarta: Pusat Bahasa

Sardiman. 2012. Interaksi \& Motivasi Belajar Mengajar. Jakarta : RajaGrafindo Persada KhanzaSavitra(https://dosenpsikologi.com/peran-guru-dalam-proses-pembelajaran)

Musfah, Jejen. 2011. Peningkatan kompetensi Guru Melalui Pelatihan dan Sumber Belajar Teori dan Praktik. jakarta : kencana prenada media group 